\title{
Szerkesztői bevezető
}

Negyedik évfolyamában lép az idei első számmal az Opus et Educatio, az elmúlt két hónapban a 12. számát szerkesztettük a még mindig kisgyermekkorában lévő online szakmai folyóiratunknak. A tavalyi váltás, mely az Open Journal System-re történő átállással újabb lépés volt a lap színvonalának és technikai elérésének javítása útján, markánsabbá vált a lektorálásra vonatkozó szakmai vállalásunk is. Mint ahogy a lap elektronikus nyitóoldalán olvasható: folyóiratunkban kettős bírálati rendszerben - double-blind peer-review - értékeljük a beküldött kéziratokat. $\mathrm{E}$ folyamatban a cikk szakmai tartalmának megfelelően felkészült, tudományos minősítéssel rendelkező bírálókat kérünk fel, akik a szerző személyes adatait nem ismerhetik meg, a bírálat objektivitása érdekében. Folyamatban van a megjelent írások tudományos életünkben komoly jelentőséggel bíró indexálásának is a bővítése, jelenleg a DOI átfogó alkalmazását készítjük elő. Ez a digitális azonosító lehetővé teszi, hogy a megjelenő írásokat digitális hálózatokon állandóan azonosítani lehessen, és a rájuk vonatkozó kurrens adatokat el lehessen érni. Ezzel első sorban a doktoranduszok, kutatók publikációinak az elérhetőségét, hivatkozási lehetőségét szeretnénk megteremteni.

Természetesen a technikai, formai innovációkon túl lényeges a tartalom frissessége. A cím (Munka és Nevelés) tematikailag is kötelez, s ha módunk van, úgy igyekszünk tematikus számokkal markánsabbá tenni az Opus et Educatio-t. E törekvésünk jegyében a Magyar Pedagógiai Társaság 2016. november 29-én a Budapesti Műszaki és Gazdaságtudományi Egyetemen „A pedagógia új dimenziói" címmel tartott konferenciájának előadásai és szekció összefoglalói képezik e számunk gerincét. E tanácskozás a tavaly 125. születésnapjáról ünnepi évvel megemlékező Magyar Pedagógiai Társaság tudományos záró konferenciája volt. Sajátos módon kevésbé a múlt felidézése és a történelmi tapasztalatok összegzése volt a cél. A XIX. század utolsó évtizedében a hazai progresszió egyik jelenünkben is aktív szakmai jelenléttel bíró szervezete, húen az alapítók eredeti szándékához, előre tekintett, s a pedagógiára érezhetően jelentős új tudományok képviselőit, illetve általuk új tudományos eredményeket számára biztosított korszerű fórumot.

A négy plenáris előadást a Tanulmányok rovatban teljes terjedelmúkben közöljük. A pedagógiai elméletet és gyakorlatot korunkban egyre jelentősebb eredménnyel támogató kognitív pszichológia képviselői - Topál József és Király Ildikó, s az írott cikk esetében társszerzőként Baross Júlia - a társas tanulási képességek neurofiziológiai alapjairól szóló tudásunk mély átalakulásáról, s az ebből következő oktatáselméleti felismerésekről, valamint a kisgyermekkorban különösen nagy jelentőséggel bíró természetes pedagógia kognitív pszichológiai sajátosságairól szóltak. Különösen izgalmas az a kérdés, hogy hogyan adják át egymásnak egy szociális csoport tagjai a történelmük által felhalmozott kulturális tudást? Hogyan tanul egy kisgyermek a közösségének tagjaitól? A kultúra, és az ehhez kapcsolódó tudás, ennek átadásának folyamata, az egyik 
legkülönlegesebb jellemzője az emberi társadalmaknak - de egyben az egyik legnehezebben feltárható jelensége is.

Bár a pedagógia sokak szemében konzervatív gondolatokat ébreszt, e dilemmát a filozófiai gondolkodás szintjén, a jelen fejlődési tendenciáit érzékeltetve, helyezte Nyíri Kristóf igényes tudományos keretbe. Előadása, illetve cikke „Konzervatív pedagógia a 21. Században” sokak számára nyújthat tudományos orientációt a pedagógia elméletének és gyakorlatának jelenkori átalakulásának megértéséhez. Arra az elméletileg egyáltalán nem egyszerű kérdésre keresi a választ a szerző, hogy mit is őriz a konzervatív? A szerző erre ma úgy válaszol, hogy a konzervatív a jövőt őrzi, közelebbről azt a tudásteljességet, amely a jövő nemzedékek életlehetőségei megteremtéséhez szükséges. Bengi László „A tanár alakja a magyar irodalom történetében” cikke arra hívja fel a figyelmünket, hogy az irodalom és tanítás összefüggése a puszta tematikus kapcsolatnál lényegesen szorosabb: mindkét területnek lényegi sajátossága, hogy szüntelen szembesülni kénytelen önnön legitimációjának problémájával. Ezért az iskolához kapcsolódó irodalmi múvek olyan reflektált és kritikai viszony kialakítására ösztönözhetnek, amely relevánsan hozzájárul a napjainkban is komoly kihívásokkal szembesülő oktatás megújulásához.

A négy igényes tanulmány e számunk karakterét meghatározta, ugyanakkor a teljesség igénye, $\mathrm{s}$ a nyitott kommunikációra való törekvés jegyében a pedagógiai új dimenzióit nem csupán érzékeltetik, hanem az ezekről való közös gondolkodást is bemutatják azok a szekcióösszefoglalók, melyek Kraici Mária (A tanulóképesség határai és csatornái - a szociális determináció), Fábri György (Konzervativizmus és modernizálás az oktatásügyben) és Pap Dalma (A digitális környezet, mint a tanulás elsődleges közege) tollából készültek a közel másfélszáz konferencia részvevő által folytatott szakmai konzultációt érzékelteti.

E számunk is relatíve terjedelmes (közel 8 ív), melynek oka, hogy a hagyományos rovataink is érdekes írásokat tartalmaznak. A Munkaügyi Szemle rovatunkban a pályaorientáció és tanárképzés összefüggéseiről Borbély-Pecze Tibor Bors és Suhajda Csilla Judit írását, Varga Károly „A leadership vizsgálata magyarországi sportegyesületeknél”, valamint Horváth István „Mit ígér a múlt? A kollektív intézmények funkcióvesztésének gyökerei a korábbi munkajogi szabályozásban" címú tanulmányait ajánlom az olvasók figyelmébe. További két tanulmány örvendetes módon lapunkban újabb közleményt beküldő szerzőktől - Kovács Ilma és Zerényi Károly - kerül közlésre, ami jelzés, hogy formálódik egy olyan szerzői kör, mely írásaival bizalommal fordul az Opus et Educatio-hoz. Változatlanul folytatjuk a Projektekről sorozatunkat, s két recenzió is szerepel az olvasásra ajánlott írások között, remélve, hogy olvasótáborunk is egyre inkább bővül.

Budapest, 2017. február

Benedek András főszerkesztő 